\title{
Further Reflections on Sandra Lipsitz Bem's Impact
}

\author{
Campbell Leaper ${ }^{1}$
}

Published online: 25 March 2017

(C) Springer Science+Business Media New York 2017

\begin{abstract}
Over 20 years since her last published new work, Sandra Lipsitz Bem's ideas continue to inspire and influence many contemporary researchers - as reflected in the many excellent papers appearing in the two special issues of Sex Roles. In my review, I highlight how Sandra Bem was repeatedly at the vanguard of the intellectual zeitgeist that shaped the psychology of gender over the last four decades. Notably, Bem was at the forefront of second-wave feminist psychology in the 1970s. In this regard, she challenged androcentric ways of thinking about gender and sexuality. Moreover, she helped to expand our notion of gender and gender identities beyond bipolar or dichotomous models. By extension, her androgyny and gender schema theories pushed people to consider the multifaceted features of gender and sexuality. Bem heralded the benefits of greater flexibility and gender equality for children as well as adults. In addition, she was one of the first psychologists to study how language and gender divisions are intertwined. Finally, she was on the forefront of researchers addressing heterosexism and genderism. The papers appearing in the two special issues are used to illustrate each of these important contributions.
\end{abstract}

Keywords Feminism - Sexism · Gender identity · Gender roles $\cdot$ Gender attitudes $\cdot$ Gender development .

Heterosexism $\cdot$ Language

Campbell Leaper

cam@ucsc.edu

1 Department of Psychology, University of California, Santa Cruz, Room 277 Social Sciences 2, 1156 High Street, Santa Cruz, CA 95064, USA
I consider it a privilege to have been invited to conclude the second of two special issues of Sex Roles in honor of Sandra Lipsitz Bem (Keener and Mehta 2017a, b). Given the number and the scope of interesting papers in these two issues, however, I find myself with few (if any) original ideas to add to what these scholars have observed. The issue editors, Keener and Mehta, have presented excellent introductions to each issue in which they highlighted key contributions of each paper. In addition, Lips (2016) offered a thoughtful concluding article after the first special issue that distilled many of the key themes across papers (and shared by many of the papers in the current issue). Also, authors in each issue have written excellent review articles summarizing, interpreting, and extending Bem's ideas and work (Balzer Carr et al. 2015; Dean and Tate 2016; Golden and McHugh 2016; Liben and Bigler 2015; Martin et al. 2016; Starr and Zurbriggen 2016). Furthermore, most of the empirical studies reported in these issues included extensive discussions of Bem's ideas and impact. Hence, readers will likely find that my reflections overlap with ideas presented in the other papers.

To begin my commentary, I share some ways that Sandra Bem affected my own work. Afterward, I will summarize Sandra Bem's major intellectual contributions and how they have shaped psychologists' thinking about gender and sexuality. I will reference articles in both special issues of Sex Roles to illustrate these points (with more emphasis on those in the current issue).

\section{Personal Impact}

Many of the authors in the two special issues mentioned Sandra Bem's influence on their own thinking. I also wish to acknowledge how her ideas affected my own development as a research psychologist. As a graduate student in psychology 
at UCLA in the 1980s, a turning point occurred when I enrolled in a seminar on the Psychology of Gender taught by Nancy Henley and Anne Peplau. Among the assigned readings was Sandra Bem's (1976) "Probing the Promise of Androgyny." Although I had started my graduate career researching children's language development and language disorders, I was becoming increasingly interested in gender. (Coincidentally, Sandra Bem's [1967] first published research also focused on children's language use.) However, with the help of Nancy Henley's mentoring, I started to consider how language is used to define and maintain gender divisions in social interactions and society. Learning about psychological androgyny affected this shift in my work.

In my first study on gender and language, I examined selfperceived psychological androgyny in relation to communication style during conversations among mixed-gender undergraduate pairs (Leaper 1987). This was followed by my dissertation research (Leaper 1986, 1991) in which I examined gender-related variations in children's speech. For this research, I conceptualized speech acts based on two intersecting dimensions - influence (assertion) and involvement (affiliation). Analogous to the androgyny model, I classified speech acts as either high in both dimensions (collaborative acts: both assertive and affiliative), high in only one dimension (controlling acts: high in assertion but low in affiliation; obliging acts: high in affiliation but low in assertion), or low in both dimensions (withdrawal). In subsequent years, I continued to study language and gender based on this model (e.g., Leaper 2000). (At the same time, my research program expanded to other facets of gender and sexism.)

Whereas the androgyny model inspired my twodimensional conceptualization of speech acts, I avoided using the terms feminine and masculine to characterize the affiliative and the assertive dimensions, respectively — or to use the term androgynous to describe speech acts that reflected high levels of both dimensions. Lott (1981) had critiqued the terminology used in the androgyny model as essentialist. That is, she argued that referring to instrumental/assertive behaviors as masculine and referring to expressive/affiliative behaviors as feminine reinforce the notion that certain behaviors are inherently male or female (also see Leaper 1995). Alternatively, Lott proposed these behaviors should be seen as human attributes that can be expressed in all individuals. Rather than describe certain behaviors as feminine or masculine, she recommended using terms such as expressive/affiliative or instrumental assertive, respectively, that reflect their pragmatic functions. In later years, Bem herself came to view that the concepts of androgyny, masculinity, and femininity could "be said to reproduce precisely the gender polarization that it seeks to undercut" (see Bem 1993, p. viii). Today's scholars continue to wrestle with these issues (see Wood and Eagly 2015; and Keener 2015; Mehta 2015; Schmader and Block 2015, for accompanying comments).
Having shared ways that Sandra Bem shaped my own thinking and scholarship, I turn next to her impact on the psychology of gender and sexuality over the last 40 years. I consider how her insights frequently captured and helped to define the intellectual zeitgeist at key moments.

\section{Bem at the Vanguard of the Intellectual Zeitgeist}

Sandra Lipsitz Bem was at the vanguard in advancing many ideas about the psychology of gender and sexuality. Her influence is reflected in the excellent papers appearing in the two special issues of Sex Roles (Keener and Mehta 2017a, 2017b). The number and the range of these articles speak to the reach that her ideas and work continue to have in psychology since the publication of her last new work nearly 20 years ago. Bem's impact and stature in psychology is especially remarkable in relation to the relatively limited number of her published works. Among Sandra Bem's papers on gender or sexuality, she has approximately 12 empirical articles, four theoretical review articles, three book chapters, five commentaries or replies, and two books (based on a PsycINFO search, retrieved December 30, 2016). However, her work has been extensively cited (see Golden and McHugh 2016; Starr and Zurbriggen 2016). For example, Bem's most cited paper is her 1974 article on "The Measurement of Psychological Androgyny," which has 2808 citations (PsycINFO, retrieved December 30,2016). This same paper was considered one the "20 most controversial studies published in child psychology" in a survey of developmental psychologists (Dixon 2014, p. 8). The survey did not define "controversial" for the respondents; yet, the word seems befitting when one considers it is synonymous with argumentative and contentious. Namely, Sandra Bem helped to start an argument in psychology about the meanings of gender and sexuality; moreover, she contested the status quo in society (Bem 1993, 1998; also see Balzer Carr et al. 2015; Dean and Tate 2016, in this issue; and see Golden and McHugh 2016; Liben and Bigler 2015 , in the previous special issue).

From approximately 1973 to 1998 , Sandra Bem both reflected and helped to define the intellectual zeitgeist shaping the psychology of gender and sexuality. Her legacy is seen in multiple and overlapping ways. As I review in the following, these include five areas. First, Bem was at the vanguard of feminist psychology as it began to flourish in the 1970s. Second, her androgyny model challenged traditional views of gender (or gender identities) as polar opposites. In later work, she further called into question the conceptualization of gender as a binary construct. Third, Bem promoted a gender schema theory with the accompanying proposal that individuals did not have to view the world in gender-stereotypical ways. Fourth, Bem was among the first to consider the possibility that traditional gender socialization during childhood 
was neither inevitable nor desirable. Finally, there are other important topics and issues that she addressed in other papers that foreshadowed trends seen later in the field. I next briefly review each of these contributions.

\section{Feminist Psychology}

As Dean and Tate (2016) observed in the current issue, Sandra Bem's work had an overall concern with social justice and equality, which was specifically applied to the analysis of sexuality and gender. The culmination of Bem's feminist approach is encapsulated in her 1993 book, The Lenses of Gender: Transforming the Debate on Sexual Identity. The metaphor of a lens was used to highlight some of the hidden assumptions about sex and gender that are internalized in individuals and enacted in society; these lenses shape how people think and act in ways that perpetuate heterosexual male dominance. The three lenses of gender are androcentrism (male as the norm; female as the deviant), gender polarization (use of a male/female binary as a pervasive organizing principle in everyday life), and biological essentialism (gender polarization as inevitably rooted in the biological natures of women and men). These arguments both reflected and advanced feminist psychology.

Looking back, we can recognize how Bem was at the forefront of second-wave feminist psychology (see Dean and Tate 2016; Golden and McHugh 2016). In the 1970s, many women (and some men) in psychology were examining ways that sexism and traditional gender roles were manifested in people's thinking and actions; in addition, feminist psychologists were challenging psychology's own androcentric biases (see Shields 2015, for a review). Sandra Bem's first published article on gender (co-authored with Daryl Bem) examined how the wording in job advertisements could contribute to sex discrimination (Bem and Bem 1973a). Her subsequent work on psychological androgyny and gender schemas challenged traditional notions of gender. That is, she advocated a conceptualization that went beyond views of women and men as opposites. Bem $(1993,1995)$ later extended her argument when she advocated for non-binary models of sex and gender. As Balzer Carr et al. (2015) explain in the present issue, these ideas have since become more widespread, as illustrated in the increasing acceptance of transgender, gender queer, or gender-fluid identities.

Also in the current issue, Bailey and LaFrance (2016) describe a study they conducted on adults' androcentric thinking. When participants were asked to select from male or female faces that reflected "a typical human," men (but not women) were more likely to pick male than female faces. This work parallels earlier research on the use of masculine pronouns (he/his) to refer generically to all persons (e.g., When a person gets a gift, he is usually happy). In the latter work, researchers found that people were more likely to imagine male than female characters (see Leaper 2014a, b, for a review). To avoid the unnecessary marking of gender in speech and to move beyond gender binaries, some people have advocated using gender-neutral nouns and pronouns; for example, this includes substituting "he" and "she" with the gender-neutral "ze" (see Bigler and Leaper 2015; Leaper 2014a). However, Bailey and LaFrance's study suggests that androcentric thinking may still occur even when genderneutral language (e.g., "human") is used. Indeed, the authors' research offers a clear illustration of the androcentric lens of gender articulated in Bem's (1993) feminist psychology.

\section{Psychological Androgyny and Gender Schema Theory}

With the resurgence of the feminist movement in the $1960 \mathrm{~s}$ and 1970s, many psychologists were questioning the desirability of traditional gender roles as well as how they were conceptualized (see Shields 2015). Bem helped to lead the way in 1974 when she published her landmark article on psychological androgyny. As mentioned earlier, this paper is her most frequently cited publication.

Earlier models had characterized gender identity along a single dimension with psychological femininity and masculinity as polar opposites. In contrast, Bem (1974) conceptualized them as two independent dimensions. Psychological femininity emphasized expressive, socioemotional, or affiliative traits whereas psychological masculinity reflected task-oriented, instrumental, or assertive traits. The androgyny model additionally allowed for the dual endorsement of both sets of traits, known as psychological androgyny. Moreover, Bem argued that androgyny was more adaptive and associated with greater psychological health (Bem 1976; Bem and Lewis 1975). At the time, other psychologists were advancing similar ideas (Block 1973; Hefner et al. 1975; Spence et al. 1974); most notably, Spence and Helmreich's (1978) androgyny model and Personal Attributes Questionnaire (PAQ) had impacts comparable to Bem's model and the Bem Sex-Role Inventory (BSRI). Nonetheless, Bem was clearly among the leaders in advancing these new conceptions of gender identity and gender roles.

In the 1980s, Sandra Bem tapped into another emerging zeitgeist when she reformulated the androgyny model into her gender schema theory (Bem 1981). This 1981 paper appears to be Bem's second most cited work (1380 citations according to PsycINFO, retrieved December 30, 2016). Bem proposed that people's conceptions of themselves in terms of psychological femininity and masculinity functioned as schemas that guide their thinking and behavior. We see other psychologists advancing gender schema theories (Liben and Signorella 1980; Markus et al. 1982; Martin and Halverson 1981) at the same time that schematic-processing models in cognitive psychology were being extended to the study of gender. In the first special issue of Sex Roles, Starr and 
Zurbriggen (2016) as well as Liben and Bigler (2015) presented comprehensive reviews of Bem's gender schema theory and its impact.

As originally formulated, Bem (1974) proposed that psychological androgyny would allow for greater flexibility and adjustment. That is, if a person can be assertive as well as affiliative, it allows for a greater repertoire of behavioral skills to deploy across a variety of settings (see Martin et al. 2016, in the prior special issue). However, because psychological androgyny was based on people's self-perceived traits, researchers sought to test whether people's BSRI or PAQ scores predicted their behavior (see Mehta et al. 2016, in current issue; Keener and Strough 2016, in first special issue). Over time, researchers noted limitations in the BSRI instrument and its predictive validity (see Golden and McHugh 2016; Lips 2016; Martin et al. 2016; Starr and Zurbriggen 2016, in first special issue).

One of the important intellectual contributions of Bem's androgyny model and gender schema theory was to conceptualize gender identities as entailing multiple dimensions or domains. In the androgyny model, the focus was on people's self-perceived instrumental/assertive traits ("masculinity") and expressive/communal traits ("femininity"). Since the introduction of androgyny models, research psychologists have expanded the type and number of dimensions that underlie gender identities (see Huston 1983; Tobin et al. 2010). According to Liben and Bigler (2002, 2015), these include traits, activities, and roles.

Other multidimensional models have addressed the evaluative qualities associated with one's gender group identity. For example, Perry and his colleagues highlighted self-perceived gender typicality, gender contentedness, and felt pressure as relevant identity dimensions (Egan and Perry 2001; Tobin et al. 2010). The latter approach guided some of the papers seen in the current issue (Lemaster et al. 2015; Pauletti et al. 2016) as well as the first special issue (Martin et al. 2016; Menon 2016).

Some papers in the current special issue went beyond measuring only self-ratings of feminine- and masculinestereotyped personality characteristics as indices of gender identity. Utilizing a broader model of gender identity, Mehta and her colleagues (2016) in the current issue examined people's self-perceived instrumental and expressive traits as well as their gender reference group identity (i.e., strength of connection to gender in-group). By comparing these two facets of gender identity, they discovered that college students' preference for same-gender friends was more strongly related to one component (reference group identity) than to another (selfperceived traits). Employing a comparable strategy, Yang and Merrill (2016) in this issue also considered two sets of gender self-concept dimensions - personality attributes (instrumental and expressive traits) and cognitive styles (analytic and intuitive) - in relation to undergraduates' wayfinding competence (i.e., sense of direction). The researchers identified some ways that each of the gender-related domains were related to women's and men's wayfinding competence to varying degrees. These two studies suggest that some dimensions of gender identity may be more related to certain outcomes than to other dimensions, whereas other dimensions may be more related to different outcomes (see Tobin et al. 2010; Wilson and Leaper 2016; Wood and Eagly 2015).

Another recent conceptual advance is the recognition that gender group identities are not necessarily exclusive. Just as Bem (1974) posited that self-perceived feminine-stereotyped and masculine-stereotyped traits are not opposites, many contemporary researchers have recognized that group identities are potentially fluid (see Balzer Carr et al. 2015 in current issue). Accordingly, we see the emergence of another intellectual zeitgeist. In both special issues, researchers presented a revised model of psychological androgyny based on children's dual identification or combined affiliation with girls and boys. For Martin et al. (2016) in the prior special issue, as well as for Pauletti et al. (2016) in the current issue, an androgynous identity occurs when children consider themselves typical of both girls and boys. In an analogous manner, Bukowski et al. (2016) in the current issue defined psychological androgyny as children's liking of both same-gender and other-gender peers. In all three studies, children's psychological well-being was positively related to these alternative operationalizations of androgyny. Each set of researchers argued that these expressions of androgyny allow for greater adaptive flexibility in relation to different situations - as Bem $(1974,1976)$ had proposed nearly four decades ago.

Besides evaluating felt gender typicality in relation to people's self-concepts, another novel strategy is to examine the degree that individuals perform a set of behaviors that are common among same-gender peers. In their study in the current issue, Fleming et al. (2016) considered a wider range of gender-typed behavioral characteristics than those assessed in the BSRI or PAQ. They utilized the national Add Health dataset of U.S. adolescents to define psychological masculinity and femininity in terms of behaviors that were more typical among young women (e.g., crying, doing work around the house, thinking of self in terms of weight) or more typical among young men (playing active sport, playing video/ computer games). Using this strategy, the researchers examined the likelihood that adolescents engaged in a violent fight in the prior 12 months. They found fights were more likely among male adolescents who scored higher on their index of same-gender similarity. Consistent with Bem's (1976) earlier assertions, the performance of traditional masculinity may be maladaptive for many boys and men.

\section{Children's Gender Development}

Although Sandra Bem published only a few papers on children's gender development, she deserves recognition for being one of the first psychologists to address the topic from an 
overtly feminist perspective. In 1983, she published a paper in Signs entitled "Gender Schema Theory and its Implications for Child Development: Raising Gender-Aschematic Children in a Gender-Schematic Society." At the time, many developmental psychologists had been studying facets of children's gender development, such as the emergence of gender identity, gender stereotyping, and gender-typed play preferences. However, with few exceptions, these investigations generally focused on documenting typical gender development, and they did not directly question whether traditional gender development was desirable or inevitable. Bem (1983, 1989) challenged these notions, and she countered that gender development was malleable. That is, she argued it was possible to raise children to be gender-aschematic. Bem strived to enact this ideal in her own life, as accounted in her 1998 autobiography aptly entitled, An Unconventional Family (also see Golden and McHugh 2016).

Many of the papers in both special issues of Sex Roles have related Bem's ideas to our understanding of children's gender development (current issue: Bukowski et al. 2016; Fleming et al. 2016; Pauletti et al. 2016; also in prior issue: Liben and Bigler 2015; Martin et al. 2016; Menon 2016). Furthermore, in the present issue, Lemaster et al. (2015) took a lifespan developmental approach to examine variations in psychological androgyny across adulthood (also see Keener and Strough 2016; Mehta and Dementieva 2016; Starr and Zurbriggen 2016, in the first special issue). Recently, Sandra Bem's work was celebrated in two separate meetings of the Gender Development Research Conference (Leaper 2014b; Mehta and Keener 2016) that were attended by many authors who have contributed to the two special Sex Roles issues. Thus, Sandra Bem's ideas have proven influential in the thinking of many feminist scholars studying children's gender development.

\section{Bem's Additional Insights}

There are other aspects of Bem's work for which she is less well known but reflect well on her early insights into important topics and concerns in feminist psychology. I note these briefly below.

\section{Gender, Language, and Communication}

The influence of language on people's thinking was Bem's earliest focus as a researcher. In her first published paper (based on her dissertation research), she examined children's use of language as a means of self-instruction (Bem 1967). Then, a few years later, she conducted her first study on gender (co-authored with Daryl Bem) testing how the wording in job advertisements could contribute to sexist discrimination (Bem and Bem 1973a). Their study occurred at a time when feminist researchers were increasingly examining ways that language defines and reinforces gender roles (see Thorne and Henley 1975; also see Bailey and LaFrance 2016, in this issue). In a few of her subsequent studies, Bem would return to examining other facets of language and communication in people's social interactions (Andersen and Bem 1981; Bem et al. 1976; Lewittes and Bem 1983). Once again, we see Bem at the forefront in a research topic-language and genderthat would subsequently take off (see Leaper 2014a).

\section{Gender Bias in Academic Achievement}

One of Sandra Bem's earliest papers considered the problem of gender bias in academic achievement (Bem and Bem 1973b). In a paper entitled, "Liberating the Female Student," Bem and Bem (1973b) considered the obstacles that many girls and women confront in school and occupations that limit their ability to reach their full potential. Although this appears to be her only paper addressing the topic of gender bias in education, I mention it because once again it reflects Bem's keen insight into issues that would gain more attention. In the subsequent decades, an increasing number of researchers and policymakers have addressed the problem of gender bias in educational attainment (e.g., American Association of University Women 1995; Leaper and Brown 2014).

\section{Heterosexism and Anti-LGBTI Bias}

Among her final published works, Sandra Bem extended her social-justice concerns to LGBTI prejudice, heterosexism, and genderism. In her last empirical studies, Bem and her colleagues examined factors related to prejudice against people with AIDS (e.g., Schellenberg and Bem 1998). Also, she published a 1995 review paper poignantly entitled, "Dismantling Gender Polarization and Compulsory Heterosexuality: Should We Turn the Volume Down or Up?" In this essay, Bem argued for moving further beyond gender dichotomies as well as against heterosexism. As she had started to do in her model of psychological androgyny, Bem was advocating for a more inclusive conceptualization of gender and sexuality. Once again, we see her at the vanguard in what increasingly became a wider call for greater acceptance of gender and sexual diversity in psychology and society at large (see Balzer Carr et al. 2015; Dean and Tate 2016; Golden and McHugh 2016). In the current issue, Balzer Carr and colleges (Bigler and Leaper 2015) offer a compelling review that articulates ways that Bem's ideas can complement current work on queer theory that contests traditional binary constructions of man/woman and straight/gay.

\section{Closing Thoughts}

As I reviewed Sandra Bem's work for this commentary, I was struck by the many ways that she was in the vanguard of 
various intellectual zeitgeists that shaped the psychology of gender over the last four decades. I have highlighted some of the important ways this occurred (also see Golden and McHugh 2016). First, she was at the forefront of secondwave feminist psychology in the 1970s. In this regard, Bem challenged androcentric ways of thinking about gender and sexuality. Moreover, Bem helped to expand our notion of gender and gender identities beyond bipolar or dichotomous models. By extension, her androgyny and gender schema theories pushed people to consider the multifaceted features of gender and sexuality as well as the advantages of greater flexibility and equality for all children and adults. Whereas people mostly associate Bem with her work on psychological androgyny and gender schemas, we also see her cutting-edge creativity in other endeavors that did not receive as much of her time. For example, Bem was one of the first persons to study how language and gender divisions are intertwined, and she was on the forefront of research which was beginning to study heterosexism and genderism. Finally, despite her last published works occurring over 20 years ago, we see that her ideas continue to inspire and influence many contemporary researchers - as reflected in the many papers that have appeared in these two special issues of Sex Roles in honor of Sandra Lipsitz Bem.

\section{References}

American Association of University Women. (1995). How schools shortchange girls. Washington, DC: Author.

Andersen, S. M., \& Bem, S. L. (1981). Sex typing and androgyny in dyadic interaction: Individual differences in responsiveness to physical attractiveness. Journal of Personality and Social Psychology, 41(1), 74-86. doi:10.1037/0022-3514.41.1.74.

Bailey, A. H., \& LaFrance, M. (2016). Who counts as human? Antecedents to androcentric behavior. Sex Roles. Advance online publication. doi:10.1007/s11199-016-0648-4.

Balzer Carr, B., Ben Hagai, E., \& Zurbriggen, E. L. (2015). Queering Bem: Theoretical intersections between Sandra Bem's scholarship and queer theory. Sex Roles. Advance online publication. doi:10.1007/s11199-015-0546-1

Bem, S. L. (1967). Verbal self-control: The establishment of effective self-instruction. Journal of Experimental Psychology, 74(4), 485491. doi:10.1037/h0024822.

Bem, S. L. (1974). The measurement of psychological androgyny. Journal of Consulting and Clinical Psychology, 42(2), 155-162. doi:10.1037/h0036215.

Bem, S. L. (1976). Probing the promise of androgyny. In A. G. Kaplan \& J. P. Bean (Eds.), Beyond sex-role stereotypes: Readings toward a psychology of androgyny (pp. 48-62). Boston, MA: Little, Brown.

Bem, S. L. (1981). Gender schema theory: A cognitive account of sex typing. Psychological Review, 88(4), 354-364. doi:10.1037/0033295X.88.4.354.

Bem, S. L. (1983). Gender schema theory and its implications for child development: Raising gender-aschematic children in a gender-schematic society. Signs, 8(4), 598-616. doi:10.1086 /493998.
Bem, S. L. (1989). Genital knowledge and gender constancy in preschool children. Child Development, 60(3), 649-662. doi:10.2307 $/ 1130730$.

Bem, S. L. (1993). The lenses of gender: Transforming the debate on sexual inequality. New Haven, CT: Yale University Press.

Bem, S. L. (1995). Dismantling gender polarization and compulsory heterosexuality: Should we turn the volume down or up? Journal of Sex Research, 32(4), 329-334. doi:10.1080/00224499509551806.

Bem, S. L. (1998). An unconventional family. New Haven, CT: Yale University Press.

Bem, S. L., \& Bem, D. J. (1973a). Does sex-biased job advertising "aid and abet" sex discrimination? Journal of Applied Social Psychology, 3(1), 6-18. doi:10.1111/j.1559-1816.1973.tb01290.x.

Bem, S. L., \& Bem, D. J. (1973b). On liberating the female student. The School Psychology Digest, 2(3), 10-18.

Bem, S. L., \& Lewis, S. A. (1975). Sex role adaptability: One consequence of psychological androgyny. Journal of Personality and Social Psychology, 31(4), 634-643. doi:10.1037/h0077098.

Bem, S. L., Martyna, W., \& Watson, C. (1976). Sex typing and androgyny: Further explorations of the expressive domain. Journal of Personality and Social Psychology, 34(5), 1016-1023. doi:10.1037/0022-3514.34.5.1016.

Bigler, R. S., \& Leaper, C. (2015). Gendered language: Psychological principles, evolving practices, and inclusive policies. Policy Insights from Behavioral and Brain Sciences, 2, 187-194. doi:10.1177 12372732215600452.

Block, J. H. (1973). Conceptions of sex role: Some cross-cultural and longitudinal perspectives. American Psychologist, 28(6), 512-526. doi:10.1037/h0035094.

Bukowski, W. M., Panarelllo, B., \& Santo, J. B. (2016). Androgyny in liking and in being liked are antecedent to well-being in preadolescent boys and girls. Sex Roles. Advance online publication. doi:10.1007/s11199-016-0638-6.

Dean, M. L., \& Tate, C. C. (2016). Extending the legacy of Sandra Bem: Psychological androgyny as a touchstone conceptual advance for the study of gender in psychological science. Sex Roles. Advance online publication. doi:10.1007 /s11199-016-0713-z

Dixon Jr., W. E. (2014). Twenty most controversial studies in child psychology. Developments: Newsletter of the Society for Research in Child Development, 57(2), 8-9.

Egan, S. K., \& Perry, D. G. (2001). Gender identity: A multidimensional analysis with implications for psychosocial adjustment. Developmental Psychology, 37(4), 451-463. doi:10.1037/00121649.37.4.451.

Fleming, P. J., Harris, K. M., \& Halpern, C. T. (2016). Description and evaluation of a measurement technique for assessment of performing gender. Sex Roles. Advance online publication. doi:10.1007/s11199-016-0657-3.

Golden, C. R., \& McHugh, M. C. (2016). The personal, political, and professional life of Sandra Bem. Sex Roles. Advance online publication. doi:10.1007/s11199-016-0674-2

Hefner, R., Rebecca, M., \& Oleshansky, B. (1975). Development of sexrole transcendence. Human Development, 18(3), 143-158. doi:10.1159/000271481.

Huston, A. (1983). Sex-typing. In E. M. Hetehrington (Ed.) \& P. H. Mussen (Series Ed.), Handbook of child psychology: Socialization, personality, and social development Vol. 4, pp. 387-467. New York, NY: Wiley.

Keener, E. (2015). The complexity of gender: It is all that and more... in sum, it is complicated. Sex Roles, 73(11-12), 481-489. doi:10.1007 /s11199-015-0542-5.

Keener, E., \& Mehta, C. M. (2017a). The past, present, and future of masculinity, femininity and gender: Honoring feminist scholar Sandra L. Bem (1944-2014), Part 1. Sex Roles, 76(9-10). 
Keener, E., \& Mehta, C. M. (2017b). The past, present, and future of masculinity, femininity and gender: Honoring feminist scholar Sandra L. Bem (1944-2014), Part 2. Sex Roles, 76(11-12).

Keener, E., \& Strough, J. (2016). Having and doing gender: Young adults' expression of gender when resolving conflicts with friends and romantic partners. Sex Roles. Advance online publication. doi:10.1007/s11199-016-0644-8.

Leaper, C. (1986). The sequencing of agency and communion in children's talk: Differences associated with age, speaker gender, and partner gender (unpublished doctoral dissertation). Los Angeles: University of California.

Leaper, C. (1987). Agency, communion, and gender as predictors of communication style and being liked in adult male-female dyads. Sex Roles, 16(3-4), 137-149. doi:10.1007/BF00289645.

Leaper, C. (1991). Influence and involvement in children's discourse: Age, gender, and partner effects. Child Development, 62(4), $797-$ 811. doi:10.2307/1131178.

Leaper, C. (1995). The use of masculine and feminine to describe women's and men's behavior. The Journal of Social Psychology, 135(3), 359-369. doi:10.1080/00224545.1995.9713965.

Leaper, C. (2000). Gender, affiliation, assertion, and the interactive context of parent-child play. Developmental Psychology, 36(3), 381393. doi:10.1037/0012-1649.36.3.381.

Leaper, C. (2014a). Gender similarities and differences in language. In T. Holtgraves (Ed.), Oxford handbook of language and social psychology (pp. 62-81). New York, NY: Oxford University Press.

Leaper, C. (Chair) (2014b, October). Honoring Sandra Lipsitz Bem (1944-2014) and her contributions to the psychology of gender. Panel at the Gender Development Research Conference, San Francisco.

Leaper, C., \& Brown, C. S. (2014). Sexism in schools. In J. Benson (Ed.), L. S. Liben, \& R. S. Bigler (Vol. Eds.), Advances in child development and behavior: The role of gender in educational contexts and outcomes (pp. 189-223). San Diego, CA: Elsevier. doi:10.1016/bs. acdb.2014.04.001.

Lemaster, P., Delaney, R., \& Strough, J. (2015). Crossover, degendering, or...? A multidimensional approach to life-span gender development. Sex Roles. Advance online publication. doi:10.1007/s11199015-0563-0

Lewittes, H. J., \& Bem, S. L. (1983). Training women to be more assertive in mixed-sex task-oriented discussions. Sex Roles, 9(5), 581596. doi:10.1007/BF00290066.

Liben, L. S., \& Bigler, R. S. (2002). The developmental course of gender differentiation: Conceptualizing, measuring, and evaluating constructs and pathways. Monographs of the Society for Research in Child Development, 67(2), 1-183. doi:10.1111/1540-5834.t01-100187.

Liben, L. S., \& Bigler, R. S. (2015). Understanding and undermining the development of gender dichotomies: The legacy of Sandra Lipsitz Bem. Sex Roles. Advance online publication. doi:10.1007/s11199015-0519-4.

Liben, L. S., \& Signorella, M. L. (1980). Gender-related schemata and constructive memory in children. Child Development, 51(1), 11-18. doi: $10.2307 / 1129584$

Lips, H. M. (2016). Sandra Bem: Naming the impact of gendered categories and identities. Sex Roles. Advance online publication. doi:10.1007/s11199-016-0664-4

Lott, B. (1981). A feminist critique of androgyny: Toward the elimination of gender attributions for learned behavior. In C. Mayo \& N. M. Henley (Eds.), Gender and nonverbal behavior (pp. 171-180). New York: Springer-Verlag.

Markus, H., Crane, M., Bernstein, S., \& Siladi, M. (1982). Self-schemas and gender. Journal of Personality and Social Psychology, 42(1), 38-50. doi:10.1037/0022-3514.42.1.38.
Martin, C. L., Cook, R. E., \& Andrews, N. C. Z. (2016). Reviving androgyny: A modern day perspective on flexibility of gender identity and behavior. Sex Roles. Advance online publication. doi:10.1007 /s11199-016-0602-5.

Martin, C. L., \& Halverson, C. F. (1981). A schematic processing model of sex typing and stereotyping in children. Child Development, 52(4), 1119-1134. doi:10.2307/1129498.

Mehta, C. M. (2015). Gender in context: Considering variability in Wood and Eagly's traditions of gender identity. Sex Roles, 73(11-12), 490 496. doi:10.1007/s11199-015-0535-4.

Mehta, C. M., \& Dementieva, Y. (2016). The contextual specificity of gender: Femininity and masculinity in college students' same- and other-gender peer contexts. Sex Roles. Advance online publication. doi:10.1007/s11199-016-0632-z.

Mehta, C. M., Hojjat, M., Smith, K. R., \& Ayotte, B. J. (2016). Associations between gender segregation and gender identity in college students. Sex Roles. Advance online publication. doi:10.1007 /s11199-016-0685-Z.

Mehta, C., \& Keener, E. (Co-chairs) (2016, October). Further reflections on Sandra Bem's contributions. Presentation at the Gender Development Research Conference, San Francisco.

Menon, M. (2016). Multidimensional gender identity and gender-typed relationship styles in adolescence. Sex Roles. Advance online publication. doi:10.1007/s11199-016-0589-y.

Pauletti, R. E., Menon, M., Cooper, P., J., Aults, C. D., \& Perry, D. G. (2016). Psychological androgyny and children's mental health: A new look with new measures. Sex Roles. Advance online publication. doi:10.1007/s11199-016-0627-9

Schellenberg, E. G., \& Bem, S. L. (1998). Blaming people with AIDS: Who deserves to be sick? Journal of Applied Biobehavioral Research, 3(2), 65-80. doi:10.1111/j.1751-9861.1998.tb00045.x.

Schmader, T., \& Block, K. (2015). Engendering identity: Toward a clearer conceptualization of gender as a social identity. Sex Roles, 73(1112), 474-480. doi:10.1007/s11199-015-0536-3.

Shields, S. A. (2015). The legacy of transformational moments in feminist psychology. Psychology of Women Quarterly, 39(2), 143-150. doi: $10.1177 / 0361684315574502$.

Spence, J. T., Helmreich, R., \& Stapp, J. (1974). The Personal Attributes Questionnaire: A measure of sex role stereotypes and masculinityfemininity. Journal Supplement Abstract Service Catalog of Selected Documents in Psychology, 4, 43. (Ms. No. 617)

Spence, J. T., \& Helmreich, R. (1978). Masculinity and femininity: Their psychological dimensions, correlates, and antecedents. Austin, TX: University of Texas Press.

Starr, C. R., \& Zurbriggen, E. L. (2016). Sandra Bem's gender schema theory after 34 years: A review of its reach and impact. Sex Roles. Advance online publication. doi:10.1007/s11199-016-0591-4

Thorne, B., \& Henley, N. M. (1975). Language and sex: Difference and dominance. Rowley, MA: Newbury House.

Tobin, D. D., Menon, M., Menon, M., Spatta, B. C., Hodges, E. V., \& Perry, D. G. (2010). The intrapsychics of gender: A model of selfsocialization. Psychological Review, 117(2), 601-622. doi:10.1037 /a0018936.

Wilson, A., \& Leaper, C. (2016). Bridging multidimensional of ethnicracial and gender identity among ethnically diverse emerging adults. Journal of Youth and Adolescence, 45(8), 1614-1637. doi:10.1007 /s10964-015-0323-z.

Wood, W., \& Eagly, A. H. (2015). Two traditions of research on gender identity. Sex Roles, 73(11-12), 461-473. doi:10.1007/s11199-0150480-2.

Yang, Y., \& Merrill, E. C. (2016). Cognitive and personality characteristics of masculinity and femininity predict wayfinding competence and strategies of men and women. Sex Roles. Advance online publication. doi:10.1007/s11199-016-0626-x. 